\title{
STUDY ON CLOUD COMPUTING PERCEPTION OF TURKISH IT SECTOR
}

\author{
Aylin Akca Okan, Tuna Hacaloglu, Ali Yazici
}

Original scientific paper In this paper an empirical study was carried out to study the Cloud Computing (CC) perception in Turkey. To this extent this study intends to determine the perception of Information Technology decision makers such as Chief Executive Officers and Chief Information Officers by means of a survey by questionnaire approach to explore 98 both public and private IT executives' understandings and concerns about CC. The survey aims to determine how $\mathrm{CC}$ is perceived by public or private organizations that are already involved in the e-transformation process. Major results of the study are as follows: both public and private sector executives have positive perception over adoption of $\mathrm{CC}$, participants think that especially web, e-mail, data storage and process management applications are adequate for CC. Lack of well-educated and experienced staff is found to be the common barrier on adopting CC by both public and private sector participants.

Keywords: Cloud Computing; e-transformation in Turkey; perception survey; statistical evaluation

\section{Analiza percepcije programskog rješenja u oblacima turskog IT sektora}

Izvorni znanstveni članak

U radu je izvršena empirijska analiza o percepciji računarstva u oblacima (Cloud Computing - CC) u Turskoj. U tu svrhu analizom je potrebno odrediti stav rukovodećih ljudi informatičke tehnologije kao što su izvršni direktori i direktori za informatičke tehnologije ispitivanjem njihovih odgovora na upitnike u svrhu dobivanja mišljenja i stavova 98 javnih i privatnih direktora IT o CC. Svrha je ispitivanja odrediti kako CC shvaćaju društvene i privatne organizacije koje su već uključene u postupak e-transformacije. Dobiveni su sljedeći bitni rezultati: direktori obadva sektora, društvenog i privatnog, imaju pozitivan stav o uvođenju CC, smatraju da naročito web, e-mail, pohranjivanje podataka i aplikacije upravljanja procesom, odgovaraju za CC. Nedostatak dobro obrazovanog i iskusnog osoblja smatra se najvećom zaprekom za uvođenje CC po mišljenju kako učesnika iz javnog tako i privatnog sektora.

Ključne riječi: analiza percepcije; e-transformacija u Turskoj; računarstvo u oblacima; statistička evaluacija

\section{Introduction}

\subsection{Background}

Cloud Computing (CC) can be defined as a structure or a type of environment, in which scalable abilities of Information Technologies (IT) are offered as a service to the users via internet technologies.

Gartner points out that $20 \%$ of all organizations will replace their IT assets with other forms of services by 2012 [1]. This prediction can be seen as a natural result of the rapid change and evolution in $\mathrm{CC}$ and it can be said that $\mathrm{CC}$ can become a driving force and, thus, it would be an important IT choice for institutions in the public sector as well as for the ones in the private sector since it tends to evolve quickly. One should note that this transformation cannot be a smooth process, though it can be anticipated that such organizations will be able to perceive this process as an important means for etransformation, and discuss and assess it carefully.

In this paper, it is aimed to investigate the effect of education level, business position, and working sector on different levels of CC perception among IT employees as well as to discover the related distribution percentages. The data and the discussion presented here may be used as an input for both developing the organizational CC strategy, and creating the infrastructure needed to change the mindset. Consequently, in order to discuss the perception level, a "Cloud Computing Perception Survey" was applied to the participants at the TBD-KamuBIB's (Informatics Association of Turkey- Union of Public IT Units) annual meeting of 2011.

Informatics Association of Turkey (TBD) was established in 1971 with a great vision of future and has become a pioneering movement of "civil community" that tries to disseminate "the culture of informatics" with its members from all layers of the society. As one of the most important working groups of TBD, Public Information Technology Units (KamuBIB) has the mission as raising awareness and creating synergy on the effective and widespread use of IT, contributing to the development of national IT policies to enable public agencies in order to provide services in an effective and productive manner, increasing exchange of information among IT Units, finding common solutions to shared difficulties with the participation of the sector. The group organizes annual meetings with different themes, in which almost 4 hundreds of people from public agencies, Information and Communications Technology (ICT) managers, universities, and private sector attend.

In the following section, the general features of $\mathrm{CC}$ will be explained and the related work will be summarized. Later, details of the survey are provided, followed by corresponding results. In the last section, the implications are summarized and suggestions as to future work.

\subsection{Cloud computing paradigm and related work}

In informatics, the term Cloud is defined as "a pool of abstracted, highly scalable and managed infrastructure capable of hosting end-customer applications and billed by consumption" [2]. Henceforth, "Cloud Computing" implies the provision, service and application of such an infrastructure. Three main services can be highlighted in this category:

- Software as a Service (SaaS),

- Platform as a Service (PaaS), and

- Infrastructure as a Service (IaaS). 
These services are offered as Public Cloud, Private Cloud, Hybrid Cloud, and Community Cloud models. The computing industry is going through a shift in the way computing is performed. There is a growing awareness among end users and enterprises to access their IT resources through $\mathrm{CC}$. Enterprises are leveraging $\mathrm{CC}$ to provide increased standardization of IT infrastructure and to lower the cost of delivering technology solutions.

In [3] the authors categorize the challenges and benefits of $\mathrm{CC}$ models. In the scope of the challenges and benefits, the following items are shortlisted (Tab. 1).

Table 1 Challenge and Benefits of CC [3]

\begin{tabular}{|ll|ll|}
\hline \multicolumn{2}{|c|}{ Challenges } & \multicolumn{2}{c|}{ Benefits } \\
\hline$\bullet$ & Trust and Privacy & $\bullet$ & Cost Reduction \\
$\bullet$ & Interoperability & $\bullet$ & Easy Scalability \\
$\bullet$ & Reliability & $\bullet$ & Increased Productivity \\
\hline
\end{tabular}

Cloud Computing 2012 Report [4] sponsored by Rackspace Hosting summarizes the reasons that may stop the organizations using $\mathrm{CC}$ :

- Concerns over confidentiality, integrity and/or availability $66 \%$

- Doubts about security $63 \%$

- Doubts about regulatory compliance $58 \%$

- Competing priorities $42 \%$

- Concerns over satisfying risk / quality / performance needs $40 \%$

- Doubts over claimed benefits $39 \%$

- Lack of management buy-in $27 \%$

- Difficulty in building a business case $27 \%$

- No impediments to use $5 \%$

- Fully utilization of cloud computing $3 \%$.

Similarly, in [5] the authors focus on five main items as the value proposition of CC:

- Reduction in ICT Spending

- Agility

- Access to Most Updated Technology

- Elimination of Procurement \& Maintenance

- Universal Resource Access.

Based on the aforementioned challenges and benefits, there exist different perceptions of CC in IT society. Several authors have addressed these different aspects of user's perceptions. For example, an empirical study conducted on a group of European and International enterprises [6] surveys the perception, assessment, and adoption of $\mathrm{CC}$ aspects. One major finding of that study indicates the higher importance of Business Drivers for the adoption of $\mathrm{CC}$, as compared to Technical Drivers.

In [7] the authors analyzed the data collected through a survey of 349 IT executives (working at German companies), and studied the opportunities and risks associated with adopting SaaS. Their findings suggest that in respect to both SaaS adopters, and non-adopters, security threats are the dominant factor influencing the IT executives' overall risk perceptions.

Also, some factors leading to technology adoption in an educational environment were studied by authors in [8] based on the Technology Acceptance Model 3 (TAM 3).

An in-depth single case study conducted in an Australian university [9] over a two-year period, including interviews with two senior IT managers, identified the motivations for adopting and avoiding $\mathrm{CC}$ environments. According to their findings, reduction in physical space for equipment, and fewer concerns on energy consumption are among the motivating factors for adoption, whereas concern over data privacy and security and losses of internal expertise are among the motivations for not wanting to shift to the Cloud Environment.

In [10] users' perceptions towards $\mathrm{CC}$ have been investigated through a survey among 183 IT specialists, professors, and employees. The results indicate that data privacy and security issues are of concern, and speed, cost, and elasticity provided by the $\mathrm{CC}$ environments are among the strong motivators for adoption.

In the present study, the CC perception in Turkey is aimed to be measured and evaluated by considering the benefits, threats and challenges brought by CC. Similarly, the questionnaire used in this survey has also been arranged based on these concerns.

\subsection{Cloud COMPUTING ADOPTION IN THE WORLD}

Cloud computing has been around in one form or another since the late 1990's. Redshift Research (a global market research company headquartered located in the United Kingdom) surveyed over 1500 public and private sector organizations across Europe, Asia, and the United States to explore the status of cloud computing on a global scale. According to their findings [11]:

- $\quad 37 \%$ of businesses globally are deploying cloud to either remotely host applications or host data (or both), with North America and Asia being most advanced in their implementation of cloud solutions. Globally, the majority of organizations are at the stage of "investigating the technology", with only a very small number $(3 \%)$ having rejected the move to cloud, outright. The adoption and level of engagement around cloud points to the fact that organization's needs and IT environments across the world are as unique as ever, leading to a staggered uptake of cloud models.

- The results point to the fact that Europe appears to be behind Asia and the US in its approach towards, and deployment of, cloud solutions. $3 \%$ of businesses in Europe have rejected the model outright with $39 \%$ stating that they have not considered a move to the cloud versus $30 \%$ in Asia and $23 \%$ in the US. There are also a smaller proportion of European businesses using the cloud for remotely hosted applications (17 $\%)$ and to host data (19\%). This number jumps to 29 $\%$ in the US for hosting applications, and $29 \%$ in Asia for hosting data.

Global results indicate that public sector organizations are primarily moving to cloud computing as a way to cut costs, largely driven by local and federal mandates. $32 \%$ of public sector organizations globally stated that government policies were accelerating cloud adoption versus only $12 \%$ that indicated it was decelerating adoption. This number is the highest in Asia where $37 \%$ stated that government initiatives were accelerating cloud adoption. $23 \%$ of global public sector IT is in the cloud, while $36 \%$ are investigating cloud solutions. 


\section{Cloud computing perceptions in Turkey and the survey applied}

\subsection{IT environment and current status in Turkey}

A recent study by [12] on CC summarizes the present status in Turkey. The size of ICT sector in Turkey is ranked as Europe's $7^{\text {th }}$ and world's $13^{\text {th }}$ market and shows a continuous growth. The share of IT is $28 \%$, and that of communication is $72 \%$ and worth USD \$24,6 billion. Also the country's software industry growth rate has increased from $5,6 \%$ to $11 \%$ in recent years, and IT hardware producers constitute approximately $40 \%$ of its market. By 2011, according to Turkish Statistical Institute (TUIK) surveys, the use of PCs and Internet access (mainly by xDSL, $89 \%$ ) in the enterprises are $94 \%$ and $92,4 \%$, respectively [13]. The following statistics have been compiled for the year 2011 by the Information Technologies and Communication Agency of Turkey (BTK - Bilgi Teknolojileri ve İletişim Kurumu) [14] (Tab. 2).

Table 2 Some statistical figures for ICT in Turkey

\begin{tabular}{|l|c|}
\hline Internet subscribers & 14,12 million \\
\hline $3 \mathrm{G}$ subscribers & 31,4 million \\
\hline 2G subscribers & 33,9 million \\
\hline GSM subscribers & 65,3 million \\
\hline Fixed phone subscribers & 15,2 million \\
\hline Mobile Internet usage & $10708533 \mathrm{Gbyte}$ \\
\hline Fiber cable length & $38835 \mathrm{~km}$ \\
\hline $2 \div 10 \mathrm{Mbit} / \mathrm{s}$ Internet access & $\begin{array}{c}82 \% \text { of the subscribers } \\
\text { (58\% in EU) }\end{array}$ \\
\hline$>10 \mathrm{Mbit} / \mathrm{s}$ Internet access & $\begin{array}{c}8 \% \text { of the subscribers } \\
(29 \% \text { in EU) }\end{array}$ \\
\hline
\end{tabular}

As in most countries, CC is a new concept in Turkey. According to studies, it has been identified that there are corporate users and considerable amounts of community networks covered by $\mathrm{CC}$ environments. However, at the enterprise level, there is no specific custom data or application available on CC. As SaaS develops, the share of the software market is expected to change based on the fact that the migration to cloud can change the market structure. Similarly, with PaaS or IaaS, the hardware market is likely to be affected, most probably in a negative direction, because enterprises migrating to clouds would prefer to use less sophisticated machinery on their own sites and, consequently, spend less on hardware. According to the ICT figures and the behavior of the potential users, the most important challenge for $\mathrm{CC}$ seems to be broadband access as well as quality and convenience for access.

\subsection{Research methodology and survey}

This is a research study which used a survey by questionnaire approach to explore IT professionals' understandings and concerns about CC. A survey by questionnaire approach was considered as many studies based on diffusion of innovation in the IS domain have used this approach to identify the factors influencing the rate of adoption $[15 \div 18]$.

In order to analyze the perception levels and approaches towards CC in Turkey, it was decided to apply a questionnaire to both private and public sector IT executives. Consequently, the Cloud Computing Perception Survey is applied to 98 participants during the annual meeting of TBD-KamuBIB in 2011 accommodating a satisfactory sample set and distribution among IT professionals.

In the survey, there are 62 questions, some of which are Likert-type (that is, the scale of 1 being 'strongly disagree' up to 5 as 'strongly agree') and the others are open-ended questions. Apart from the standard questions about the demographic data, the questions concerning the infrastructure of the institution and the cloud perception of the respondents are mainly formulated by the authors. Questions in the questionnaire were prepared in a way to determine the respondents' perception to Cloud Computing in their organization. To this extent, except the standard questions on bio-data, all the questions were compiled by the authors based on their experience in the field and cloud computing on general. At the beginning of the survey, a short definition of CC is also provided as a textual introductory material. The survey is composed of six main sections:

- In the "Demographic Information" section, information such as gender, age, education level, the sector that they work in, the field of occupation, together with items regarding internet usage is gathered through 10 questions.

- In the second section, "The Organizational and Technological Infrastructure of the Institution", it is aimed to gather the opinions of the participants about their current organizational and technological infrastructure by asking 19 questions. These questions include how frequently they update their infrastructure, the budget that they allocate to the IT assets, and their viewpoint about outsourcing.

- In the third section "Perception", the purpose is to measure perceptions regarding $\mathrm{CC}$ technology whose measurement is carried out by providing 12 hypotheses such as "Cloud Computing will cause the organization to undergo a radical change in IT", "Cloud Computing is an extension of etransformation", and similar items.

- The next section titled "Through the Eyes of the Decision-Makers of the Institutions", the perceptions regarding $\mathrm{CC}$ are measured more specifically and in detail. The purpose at this stage is for participants to evaluate the $\mathrm{CC}$ by considering their own institutions.

- The fifth section, "Challenges and Obstacles", by asking 10 questions, gathers the ideas about the challenges and obstacles that CC transformation process can pose within the scope of e-government.

- In the sixth and final section, the interoperability inside and outside the institution is examined under the "Interoperability Within/Outside the Organization" heading. There, the "Within the Organization Level" part is meant to gather the most preferential applications, which may be transformed into $\mathrm{CC}$ out of these already transformed into eorganization application or which are likely to be so later. Similarly, in the "Outside the Organization Level" part, the same issue has been addressed, but this time from the inter-organizational perspective. 
All in all, this survey aims to measure how $\mathrm{CC}$, as an extension of e-transformation, is perceived by the public or private organizations that are already involved in the etransformation process or which will be in this process in some form soon.

\section{Evaluation of survey results}

\subsection{Assessment by percentage frequency distribution}

$\mathrm{CC}$ is based on the principle of outsourcing different services and/or platforms. For this reason, while evaluating the results of the survey, additional emphasis is put on the viewpoint of the participants concerning outsourcing and this scope is studied and discussed in the first place, followed by the readiness levels and etransformation prioritization.

Within the process of creating a percentage frequency distribution, the total number of observations to be represented is first identified; then the total number of observations within each data point or grouping of data points is counted; and then the number of observations is divided within each data point or grouping of data points.

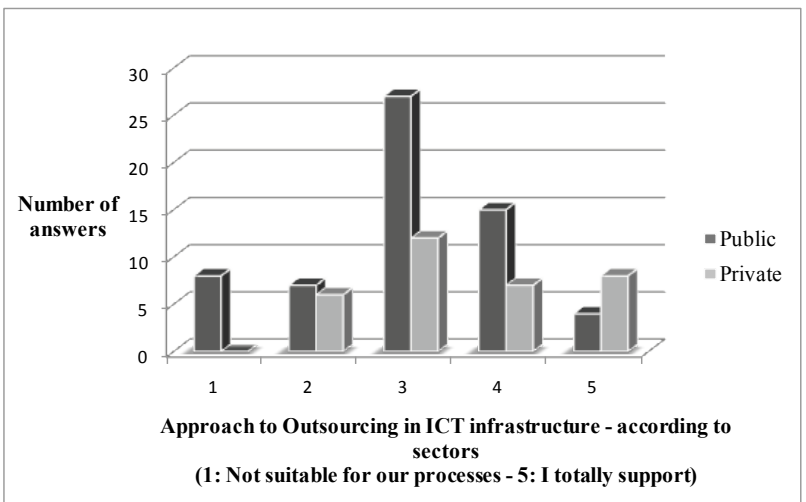

Figure 1 The approach to outsourcing in ICT infrastructure with respect to the business sector

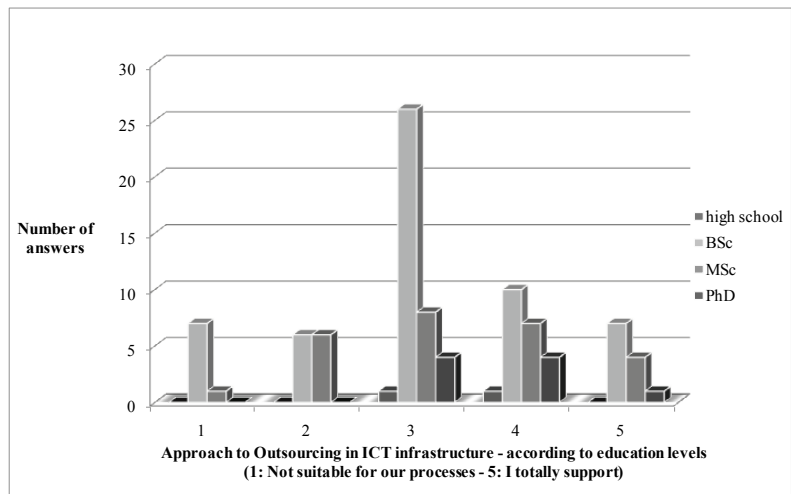

Figure 2 The approach to outsourcing in ICT infrastructure with respect to the education level

According to the results, $65 \%$ of the participants of the survey are working in the public-sector, and the rest in the private-sector. In terms of the education, $98 \%$ of the participants hold either a $\mathrm{BSc}$ or an MSc degree. It is observed that the sector (whether a public or private institution) does not affect the positive viewpoints regarding outsourcing. It can be seen that the working sector of the employees does not put a significant difference on outsourcing as Fig. 1 indicates. Given that most participants have rated the questions as 3 or above,
$75 \%$ of the public sector workers and $82 \%$ of the private-sector workers are in favor of outsourcing (Fig. 1).

Level of education and a positive approach to outsourcing appear to agree, as it is observed that $77 \%$ of the people having BSc degree and $73 \%$ of these with MSc degree, and $100 \%$ of those with $\mathrm{PhD}$ are in favour of outsourcing (Fig. 2).

Considering that one of the most important factors that may affect the adoption of CC is the ICT staff, the perceptions regarding their competence are observed by the education level and the sector of the participants. Based on the responses, generally, the competence and qualification level of ICT staff are satisfactory. However, the degree of satisfaction at the private sector (that is, those rating 3 or above) is comparatively higher than the others.

What's more, $82 \%$ of public-sector employees and 91 $\%$ of those in the private-sector believe that the ICT staff is sufficient in their respective institutions (Fig. 3).

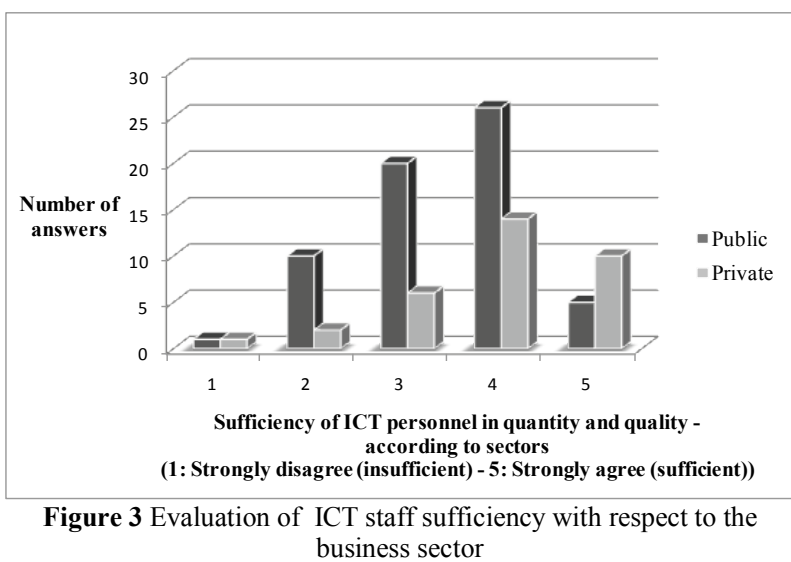

The relation between ICT staff sufficiency level and the education level is positive. However, one can see that the positive approach slightly decreases as the education level increases. In this respect, $89 \%$ of those with BSc degrees, $80 \%$ of those with MSc degrees, and $72 \%$ of possessing $\mathrm{PhD}$ degrees believe in the sufficiency of the staff in their organizations both from the quality and quantity perspectives (Fig. 4).

- $4 \%$ of the participants answered the question "which applications are suitable for the CC?" with "all the applications are suitable", while another $4 \%$ declare that there is no application suitable for such a structure. The applications listed (open-ended response) are as follows: $13 \%$ web applications, 16 $\%$ e-mail, $22 \%$ process management, $8 \%$ database, $2 \%$ social networks, and $4 \%$ Commercial Off-TheShelf (COTS) with a valid license.

- Among the responses to the statement "The inadequacies that you find in your organizational and technological infrastructure", lack of qualified staff and lack of experience attracted more attention with $19 \%$, while $16 \%$ believe that education among staff is another inadequacy. Other shortages included: number of employees with $11 \%$, software development with $9 \%$, security with $7 \%$, interest and innovative perspective with $7 \%$, the attitude of senior management with $7 \%$, lack of hardware and infrastructure with $7 \%$, and public- sector structure and organizational planning with $5 \%$. 


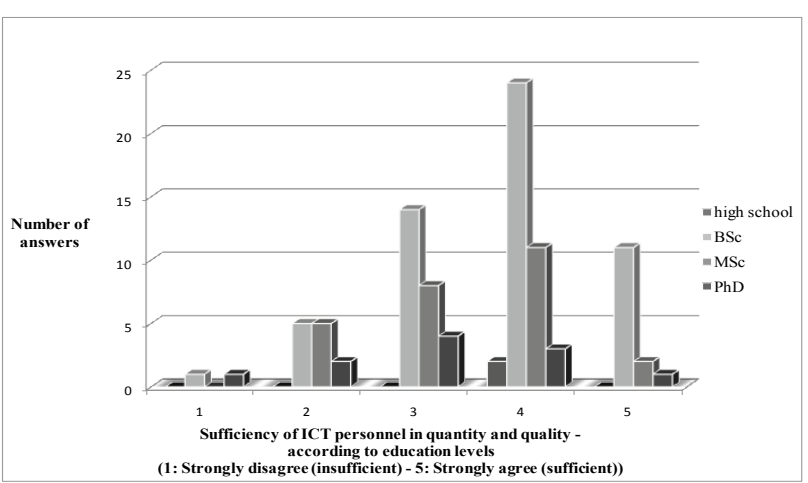

Figure 4 Evaluation of ICT staff sufficiency with respect to education level

During the detailed evaluation, using the following variables, namely $\mathrm{S} 3, \mathrm{~S} 4, \mathrm{~S} 5$, and $\mathrm{S} 16$ are determined as experimental factors in other words independent variables; where S14 and S30-41 are dependent variables. In this evaluation the effect of the independent variables such as education level, working sector, business position on the dependent variables such as perspective on outsourcing of ICT infrastructure and CC perception are investigated.

The above mentioned variables are listed below:

- S3: Education Level (high school, BSc, MSc, and $\mathrm{PhD} / 1 \div 4)$

- S4: Working sector (public and private / $1 \div 2$ )

- S5: Business Position (IT manager, IT employeesoftware, IT employee-hardware, Faculty Member, Sales and Marketing, Project Management, and others / $1 \div 7$ )

- S14: Perspectives on outsourcing of ICT infrastructure / $1 \div 5$ )

- S16: Adequacy of the ICT staff in terms of quantity and quality $/ 1 \div 5$ )

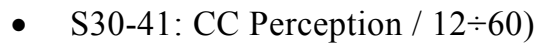

Table 3 Cloud Computing Perception - Questions $30 \div 41$

(1 strongly disagree through 5 strongly agree scale)

30. CC will cause the organization to undergo a radical change in IT.

31. CC is merely an IT model produced for commercial purposes by the companies who provide IT service.

32. CC is a developing IT concept whose maturity will take years.

33. $\mathrm{CC}$ is another name given to virtualization.

34. CC is only a temporary motivation in the IT sector.

35. Increase in CC usage may lower the cost and utilization of IT services.

36. CC usage is very risky for public institutions from the security perspective.

37. $\mathrm{CC}$ is an extension of e-transformation.

38. CC is likely to create fear of job loss among staff.

39. CC is likely to create new business areas in IT.

40. CC services are too costly to build.

41. The spread of CC will affect software development and production negatively.

In the survey, the questions as appearing in Tab. 3 are asked to evaluate CC perceptions. As a priori assumption, it is calculated that the sum of positive perception (i.e., nominal limit for positive perception) is in between 20 and 40 considering the positive responses, and the values below 20 or above 40 shows that there is a negative approach towards $\mathrm{CC}$.

The distributions in Tab. 4 are obtained in the light of the questions stated in Tab. 3, and as a result of the evaluation of the perception of $\mathrm{CC}$ perceptions in different categories. As it is seen in this table, the CC perception level has the highest rate in the specified nominal limits $(20 \div 40)$. It is also observed that the perception rate of the participants is positive regardless of the business sector and the business role where this perception rate is distributed equally for the ones who have a high school degree. On the other hand, similar conclusion is reached, that the ones with little regard to outsourcing, also support $\mathrm{CC}$ less. In addition, the CC approach of those participants who find the ICT staff insufficient both in quantity and quality is very positive. However, as the rate of adequacy increases, the perception level displays more horizontal and more approximate results.

Table 4 Percentage of Cloud Computing Perception with respect to

\begin{tabular}{|c|c|c|c|c|}
\hline \multirow{2}{*}{\multicolumn{2}{|c|}{ Categories }} & \multicolumn{3}{|c|}{ Ranges of perception level (\%) } \\
\hline & & \multirow{2}{*}{$\begin{array}{c}1 \div 19 \\
0\end{array}$} & \multirow{2}{*}{$\frac{20 \div 40}{50}$} & \multirow{2}{*}{$\begin{array}{c}21 \div 60 \\
50\end{array}$} \\
\hline S3 & High school & & & \\
\hline & $\mathrm{BSc}$ & 10 & 83 & 6 \\
\hline & MSc & 9 & 91 & 0 \\
\hline & $\mathrm{PhD}$ & 11 & 89 & 0 \\
\hline S4 & Public & 9 & 87 & 4 \\
\hline & Private & 13 & 80 & 7 \\
\hline S5 & IT manager & 6 & 91 & 3 \\
\hline & IT employee software & 0 & 86 & 14 \\
\hline & IT employee hardware & 20 & 60 & 20 \\
\hline & Faculty member & 14 & 86 & 0 \\
\hline & Sales and Marketing & 13 & 88 & 0 \\
\hline & Project Management & 25 & 75 & 0 \\
\hline & Others & 18 & 82 & 0 \\
\hline $\mathrm{S} 14$ & 1 (least) & 29 & 71 & 0 \\
\hline & 2 & 25 & 75 & 0 \\
\hline & 3 & 7 & 83 & 10 \\
\hline & 4 & 5 & 95 & 0 \\
\hline & $5($ most $)$ & 0 & 92 & 8 \\
\hline $\mathrm{S} 16$ & 1 (least) & 0 & 100 & 0 \\
\hline & 2 & 27 & 73 & 0 \\
\hline & 3 & 9 & 86 & 5 \\
\hline & 4 & 8 & 86 & 6 \\
\hline & 5 (most) & 9 & 82 & 9 \\
\hline
\end{tabular}

\subsection{Assessment by hypothesis testing}

In this study, in addition to the overall percentage distributions, the relations among the responses are studied and examined with the hypothesis tests.

Hypothesis testing is a technique to test a claim or hypothesis about a parameter in a population. The best way to determine whether a statistical hypothesis is true would be to examine the entire population. Since that is impractical in this case, random sample from the population has been examined.

The standard four steps for hypthesis testing are applied for the data collected: stating the hypotheses, formulating an analysis plan, analyzing sample data and interpreting the results.

Level of education (S3) may affect the CC perception level $(\mathrm{S} 30 \div 41)$, perspectives on outsourcing (S14), and 
evaluation towards the adequacy of the ICT staff (S16), so our related null hypotheses are as follows:

H1: S3 is compiled from identical populations in terms of $\mathrm{S} 30 \div 41$.

H2: $\mathrm{S} 3$ is compiled from identical populations in terms of $\mathrm{S} 14$.

H3: S3 is compiled from identical populations in terms of S16.

The adequacy of the ICT staff (S16) may affect the attitudes towards the ICT outsourcing (S14) as well as the CC perception $(\mathrm{S} 30 \div 41)$, so our related null hypotheses are as follows:

H4: S16 is compiled from identical populations in terms of $\mathrm{S} 14$.

H5: S16 is compiled from identical populations in terms of $\mathrm{S} 30 \div 41$.

Working sector (S4) may have an effect on the CC perception level $(\mathrm{S} 30 \div 41)$, perspectives on outsourcing (S14), and evaluation towards the adequacy of the ICT staff (S16), so our related null hypotheses are as follows:

H6: S4 is compiled from identical populations in terms of $\mathrm{S} 30 \div 41$.

H7: S4 is compiled from identical populations in terms of S14.

H8: S4 is compiled from identical populations in terms of $\mathrm{S} 16$

The business position (S5) may affect the attitudes towards the ICT outsourcing (S14) as well as the CC perception (S30-41), so our related null hypotheses are as follows:

H9: S5 is compiled from identical populations in terms of $\mathrm{S} 30 \div 41$.

H10: S5 is compiled from identical populations in terms of S14.

$P$-value is used to accept or reject the null hypothesis. If the $P$-value is less than the significance level, then the null hypothesis is rejected. With the experimental factors stated above, the following hypotheses are tested with the 0,05 significance level (Tab. 5).

Table 5 Hypothesis Testing Results

\begin{tabular}{|c|c|c|c|c|}
\hline & $N$ & $P$ value & $\begin{array}{c}\text { Degree of } \\
\text { freedom }\end{array}$ & Median \\
\hline H1 & 82 & 0,929 & 3 & 33 \\
\hline H2 & 93 & 0,414 & 3 & 3 \\
\hline H3 & 95 & 0,436 & 3 & 4 \\
\hline H4 & 94 & 0,529 & 4 & 3 \\
\hline H5 & 82 & 0,076 & 4 & 33 \\
\hline H6 & 83 & 0,985 & 1 & 33 \\
\hline H7 & 94 & 0,249 & 1 & 3 \\
\hline H8 & 96 & 0,014 & 1 & 4 \\
\hline H9 & 82 & 0,698 & 6 & 33 \\
\hline H10 & 93 & 0,314 & 6 & 3 \\
\hline
\end{tabular}

(Although the survey was applied to 98 participants, sample size varies from one hypothesis to the other, because of the unanswered questions.)

When the education level is taken into account (S3), the following analyses related to hypotheses can be elicited:

H1: The level of $\mathrm{CC}$ perception has an equal distribution. Since a positive perception level is expected between 20 and 40, the calculated median value, 33 , is an indicator showing that $\mathrm{CC}$ is perceived positively.

H2: The approach to outsourcing in the ICT infrastructure shows an equal distribution, and the calculated median value, 3 , is the indicator that shows the probability for a chance to choose outsourcing. On the other hand, since $37 \%$ of the survey participants have given answers, above the median value, it is possible to say that there is a positive view towards outsourcing.

H3: The sufficiency in quantity and quality of ICT staff shows an equal distribution. The calculated median value, 4, constitutes evidence of staff sufficiency. Since $15 \%$ of the participants have rated that item as 5 which is above the median value, it is possible to say that no problem is envisaged concerning staff.

When the insufficiency of ICT staff is taken into account (S16):

H4: The approach to outsourcing in ICT infrastructure shows an equal distribution as the calculated median value, 3 , is the indicator showing that outsourcing can be preferred. On the other hand, since $36 \%$ of the participants gave answers that are above the median value, it is possible to say that there is a positive viewpoint regarding outsourcing.

H5: The CC perception level shows an equal distribution. Since positive perception level is expected between 20 and 40, the calculated median value, 33, is an indicator showing that $\mathrm{CC}$ is perceived positively.

When the sector of the business is taken into account (S4):

H6: The CC perception level shows an equal distribution. Since positive perception level is expected between 20 and 40, the calculated median value, 33, is an indicator showing that $\mathrm{CC}$ is perceived positively.

H7: The approach to outsourcing in ICT infrastructure shows an equal distribution, since the calculated median value, 3 , shows that outsourcing can be preferred. On the other hand, since $36 \%$ of the participants gave answers that are above the median value, it is possible to say that there is a positive viewpoint on outsourcing.

H8: Since the calculated $P$ value remains below the 0,05 significance level, the approach to ICT staff from the quality and quantity perspective does not show an equal distribution, and tends to vary with respect to the public and private sector.

When the business position is taken into account (S5):

H9: The CC perception level shows an equal distribution. Since positive perception level is expected between 20 and 40, the calculated median value, 33, is an indicator showing that $\mathrm{CC}$ is perceived positively.

H10: The approach to outsourcing in ICT infrastructure shows an equal distribution. Calculated median value, 3 , signifies that outsourcing can be preferred. On the other hand, since $35 \%$ of the participants gave answers that are above the median value, it is possible to say that there is a positive viewpoint towards outsourcing. 


\section{Discussion}

Cloud Computing (CC) is an approach that leads all institutions - regardless of public or private - to offer new solutions to problems, and change the way of doing the business. The purpose of $\mathrm{CC}$ is to offer better and highquality service at a lower cost, with sufficiently trained and not necessarily advanced IT staff, and more flexible and less complex structures. Contrary to some beliefs that circle around, the remoteness, over- virtualization, capitalistically- oriented views, $\mathrm{CC}$ is believed to offer a wide range of solutions and business opportunities. What needs to be done, however, is to facilitate access and accomplishment of expectations especially by ICT managers.

In 2011, Atilim University with the support of Informatics Association of Turkey (TBD), conducted a study examining the perception and the adoption of $\mathrm{CC}$ by IT professionals in the TBD-KamuBIB 2011 Annual Meeting. According to the answers to the open-ended questions in the survey, it is seen that organizations think that web, e-mail, and data storage and process management application are suitable for CC. Moreover, according to the organizations (public or private), the point that is most inadequate or insufficient for the adoption of CC process is the lack of well-educated and experienced staff in the organizations. Today, technical personnel is preferred to maintain the physical setup of computer systems but these people may not necessarily be aware of the intrinsic details of the services provided by the institution they work for. In [1] it is stated that "Enterprise IT staff will either be reduced or, in more enlightened organizations, be reskilled to meet new requirements." Therefore, in the face of such an obstacle with CC the number of such staff can be reduced, instead qualified employees specialized in particular services can be increased.

Statistically speaking, the perception level of CC has the highest rate in terms of the nominal limits in the light of the expected responses, hypotheses and the percentages aforementioned in this paper. Those high rates can be seen as the indicators that this concept is commonly perceived positively among professionals in Turkey. Meanwhile, such an inclination can indicate that institutions will likely focus on CC projects in the future. $\mathrm{CC}$ 's most promising features are cost reduction, duplication prevention, and space preservation not only in terms of office space but also virtualization meant to be treated as a silver bullet for the financial constraints and resource problems facing organizations or reduced budgetary expenditures for ICT. Obviously, challenges may still remain in terms of understanding, practice development and culture change, as well as logistics issues that include security and access. We hope that these findings will help the decision-makers and the investors understand the current status and realize the challenges and the preliminary work needed for increasing the positive perception of $\mathrm{CC}$.

\section{Conclusion}

$\mathrm{CC}$ as an extension of e-transformation is predicted to be a driving force by being a significant IT choice for both public and private institutions [1]. With this motivation a study of CC perception in the Turkish IT sector including public and private IT decision makers is conducted with 98 participants at the TBD-KamuBIB's (Informatics Association of Turkey- Union of Public IT Units) annual meeting of 2011. With the "Cloud Computing Perception Survey" the viewpoints about CC of different IT decision makers are intended to be collected. Major findings of the study show that the CC concept is commonly perceived positively among IT professionals in Turkey. Most suitable applications that can be transferred to clouds are found as web, e-mail, data storage and process management applications. However, as predicted by the previous studies, the $\mathrm{CC}$ adoption process will not be easy and there exist some barriers on the process for this reason institutions will approach cautiously to the adoption process. According to the results of the study, participants mostly suffer from the less educated and less experienced staff and see this issue as the drawback for transferring their business to clouds. One other finding of the study is that participants who support outsourcing less are also distant to adopt CC. Finally, this study makes just a readiness analysis of Turkish decision makers to adopt $\mathrm{CC}$ in their organization. It investigates for which applications IT executives find $\mathrm{CC}$ suitable, in which situations they are cautious to adopt CC. Therefore, the results of the study can be used as input for both the public/private industry and the academia for further researches.

\section{References}

[1] Gartner Inc. Gartner's Top Predictions for IT Organizations and Users, 2010 and Beyond: A New Balance. Stamford, CT. USA, Gartner Inc., 2010.

[2] Rhoton, J. Cloud Computing Explained. Recursive Press, 2010.

[3] Brohi, S. N.; Bamiah M. A. Challenges and Benefits for Adopting the Paradigm of Cloud Computing. // International Journal if Advanced Engineering Sciences and Technologies. 8, 2(2011), pp. 286-290.

[4] CityIQ. Cloud Computing 2012 Report: A Survey of Attitudes to Cloud Computing in Financial Services. Rackspace Hosting, 2012.

[5] Chandrasekaran, A.; Kapoor, M. State of Cloud Computing in the Public Sector - A Strategic Analysis of the Business Case and Overview of Initiatives across Asia Pacific. Frost \& Sullivan 2011 - Market Insight, 2011.

[6] Petruch, K.; Stantchev, V.; Tamm, G. A survey of ITgovernance aspects of cloud computing. // International Journal of Web and Grid Computing. 7, 3(2011), pp. 268303. DOI: $10.1504 /$ ijwgs.2011.043531

[7] Benlian, A.; Hess, T. Opportunities and risks of softwareas-a-service: findings from a survey of IT executives. // Decision Support Systems. 52, (2011), pp. 232-246. DOI: 10.1016/j.dss.2011.07.007

[8] Behrend, T. S.; Wiebe, E. N.; London, J. E.; Johnson, E. C. // Behaviour \& Information Technology. 30, 2(2011), pp. 231-240. DOI: 10.1080/0144929X.2010.489118

[9] Sarkar, P.; Young, L. Sailing the Cloud: A case study of perceptions and changing roles in an Australian university. // $19^{\text {th }}$ European Conference on Information Systems / Helsinki, 2011

[10] Motamedian, B. Users' perception towards "Cloud computing". // International Journal of Scientific \& Engineering Research. 2, 7(2011), pp. 1-10. 
[11] Redshift Research. Adoption, Approaches \& Attitudes The Future of Cloud Computing in the Public and Private Sectors. Redshift Research (sponsored by AMD), 2011.

[12] Helvacioglu Kuyucu, A. D. The Playground of Cloud Computing in Turkey. // Procedia Computer Science. 3 (2011), pp. 459-463. DOI: 10.1016/j.procs.2010.12.077

[13] TUIK. Use of Information and Communication Technology By Enterprise. Turkish Statistical Institute (TUIK). 2011. http://www.turkstat.gov.tr/PreHaberBultenleri.do?id=8632 (03.06.2012).

[14] BTK. Türkiye Elektronik Haberleşme Sektörü - Üç Aylık Pazar Verileri Raporu - 2011 Yılı 4. Çeyrek. Information Technologies and Communication Agency(BTK). 2012. http://btk.gov.tr/kutuphane_ve_veribankasi/pazar_verileri/ ucaylik11 4.pdf (03.06.2012).

[15] Premkumar, G.; Roberts, M. Adoption of new information technologies in rural small businesses. // The International Journal of Management Science. 27, 4(1999), pp. 467-484. DOI: 10.1016/s0305-0483(98)00071-1

[16] Teo, H.; Tan, B.; Wei, K. K.; Innovation diffusion theory as a predictor of adoption intention for financial EDI. // In Proceeding of International Conference on Information Systems / Amsterdam, 1995, pp. 141-153.

[17] Teo, T.; Lim, G.; Fedric, S. The adoption and diffusion of human resources information systems in Singapore. // Asia Pacific Journal of Human Resources. 45, 1(2007), pp. 4162. DOI: $10.1177 / 1038411107075402$

[18] Thong, J. An integrated model of information systems adoption in small businesses. // Journal of Management Information Systems. 15, 4(1999), pp. 187-214. DOl: $10.1080 / 07421222.1999 .11518227$

\section{Authors' addresses}

\section{Aylin Akca Okan}

Middle East Technical University

Üniversiteler Mahallesi,

Dumlupinar Bulvarı No: 1

06800 Çankaya Ankara, Turkey

E-mail: akca@ceng.metu.edu.tr

\section{Tuna Hacaloglu}

Atilim University

Kızılcaşar Mahallesi,

06836 İncek Gölbaşı, Ankara, Türkiye

E-mail: tuna.hacaloglu@atilim.edu.tr

\section{Ali Yazici}

Atilim University

Kızılcaşar Mahallesi,

06836 İncek Gölbaşı, Ankara, Türkiye

E-mail: ali.yazici@atilim.edu.tr 